\title{
FORMAÇÃO DO LEITOR LITERÁRIO NO ENSINO FUNDAMENTAL: UMA EXPERIÊNCIA COM “O MUNDO ENCANTADO DAS FADAS"
}

\author{
Gilmei Francisco Fleck ${ }^{1}$ \\ Cristian Javier Lopez ${ }^{2}$ \\ Carla Cristiane Saldanha Fant ${ }^{3}$
}

\begin{abstract}
Resumo: O gosto pela leitura não surge naturalmente em cada leitor, mas depende de como esse indivíduo vai sendo introduzido ao universo dos livros. Nessa configuração, a literatura infantil desempenha um papel importante de fornecer elementos que atraiam a atenção desse leitor. Assim, práticas que são iniciadas nos primeiros anos escolares podem contribuir para o acesso e o prazer proporcionado pela leitura. Por isso, propomo-nos a estabelecer reflexões sobre a formação do leitor literário nos anos iniciais do Ensino Fundamental e apresentar uma metodologia que se efetiva por meio de "Oficinas literárias temáticas" que abordam "O mundo encantado das fadas". Para alçar tais objetivos, ancoramo-nos em conceitos fundamentais que permeiam abordagens referentes à formação do leitor literário e o papel humanizador e transformador da literatura, como encontramos em Candido (1972; 2011), Magnani (1989), Coelho (2017), Jauss (1979), Stierle (1979), Mendoza Fillola (1994), entre outros.
\end{abstract}

Palavras-Chave: Leitor Literário. Estética da Recepção. Literatura Comparada.

\section{FORMATION OF THE LITERARY READER IN THE ELEMENTARY SCHOOL: AN EXPERIENCE WITH "THE ENCHANTED WORLD OF FAIRIES"}

\begin{abstract}
The willing for reading does not appear naturally in each reader, but it depends on how this individual is introduced to the universe of books. In this configuration, children's literature plays an important role in providing elements that attract the attention of this reader. So, practices that are initiated in the first school years can contribute to the access and the pleasure provided by reading. For this reason, we propose to establish reflections on the formation
\end{abstract}

\footnotetext{
1 Pós-doutor em Literatura Comparada e Tradução pela Uvigo/Vigo-Espanha; Doutor em Letras pela Unesp/Assis-SP. Líder do Grupo de pesquisa "Ressignificações do passado na América: processos de leitura, escrita e tradução de gêneros híbridos de história e ficção - vias para a descolonização"; chicofleck@yahoo.com.br Orcid: https://orcid.org/0000-0002-4228-2566.

2 Doutor pela UVIGO/Espanha em cotutela com a Unioeste/Cascavel-PR/Brasil; integrante do Grupo de pesquisa "Ressignificações do passado na América: processos de leitura, escrita e tradução de gêneros híbridos de história e fiç̧ão - vias para a descolonização", cj_lopez2@hotmail.com Orcid: http://orcid.org/0000-0002-7391-8395.

${ }^{3}$ Mestranda no Programa Profletras - Mestrado Profissional em Letras da Unioeste/Cascavel-PR; integrante do grupo de pesquisa "Ressignificações do passado na América: processos de leitura, escrita e tradução de gêneros híbridos de história e ficção - vias para a descolonização", ccsfant@gmail.com Orcid: https://orcid.org/0000-0002-4977-5806.
} 
of the literary reader in the early years of elementary school and to present a methodology that is developed through "Thematic literary workshops" that refer to "The enchanted world of fairies". To achieve these goals, we anchored ourselves on fundamental concepts that permeate approaches related to the formation of the literary reader and on the humanizing and transforming role of literature, such as, in Candido (1972; 2011), Magnani (1989), Coelho (2017); Jauss (1979), Stierle (1979), and Mendoza Fillola (1994), among others.

Keywords: Literary Reader. Aesthetics of Reception. Comparative Literature.

\section{Introdução}

A formação do leitor literário é um tema recorrente na sociedade atual, no entanto não se esgotam os debates sobre esse tema e sobre as possibilidades de oportunizar o encontro de gêneros literários diversificados com os estudantes desde os primeiros anos escolares, para que despertem a sensibilidade de saber escolher o que querem ler e, ao mesmo tempo, pensar sobre o que leram e sobre como a temática lida se apresenta nas relações com as pessoas que estão à sua volta.

Isso possibilita, lentamente, a construção de sentidos sobre o mundo e a interpretação desse universo que ocorre em determinado contexto, e o resultado dessas ações pode ser diferente para cada leitor/receptor. Este vai descobrir um sentido para o que lê e uma maneira de desvendar o texto, pois a compreensão sobre leitura vai além do que está escrito, é um processo que depende de conhecimentos e interesses prévios ao ato da leitura.

Para que a atividade de leitura possa se concretizar, ela deverá vir ao encontro da necessidade do leitor. Segundo Martins (1983, p. 14) “[...] dizem os pesquisadores da linguagem, em crescente convicção: aprendemos a ler lendo. Eu diria vivendo" e, de acordo com essa perspectiva, é preciso conduzir o leitor iniciante, aquele que recém está descobrindo o universo mágico das letras e palavras, a vivenciar histórias repletas de seres mágicos que povoam a imaginação e a fantasia.

Nesse contexto da formação de um leitor literário, apresentamos algumas reflexões acerca da recepção da obra literária e sobre como as personagens fantásticas podem encantar a criança leitora. Por fim, apresentarmos uma metodologia que está organizada por meio de "Oficinas literárias temáticas" sobre o tema "O mundo encantado das fadas". 


\section{Da representação da fala às magias do mundo encantado da literatura infantil}

A formação de um leitor literário, aquele que vai adquirindo o gosto pela leitura literária, que se torna consciente de que a linguagem é material artístico manipulável, de que há uma linguagem denotativa e outra conotativa que desenvolvem diferentes discursos, é um processo que deve ser iniciado simultaneamente ao da aprendizagem da leitura como habilidade de decodificação e codificação. Esse processo, aos poucos, vai ganhando amplitude, possibilitando procedimentos mais elaborados de compreensão do texto artisticamente construído à medida que a sensibilidade para a literariedade que os constitui seja desenvolvida pelo aprendiz.

Esse momento mágico em que a criança é apresentada aos signos linguísticos como meios de representar a fala e de estruturar o pensamento é crucial na trajetória de vida do sujeito e "mágico" à sua introdução ao mundo encantado das palavras. Se a ela conseguirmos juntar, também, a magia das palavras poéticas, nesse processo primeiro de aprendizagem da codificação e decodificação que, lentamente, também deve conduzir ao uso consciente da leitura e da escrita como ferramentas de ação sócio histórica - pelo efetivo letramento -, estaremos a caminho da formação de um leitor-cidadão.

O papel da literatura nesse processo é fundamental, pois

[...] tem sido um instrumento poderoso de instrução e educação, entrando nos currículos, sendo proposta a cada um como equipamento intelectual e afetivo. Os valores que a sociedade preconiza, ou os que considera prejudiciais, estão presentes nas diversas manifestações da ficção, da poesia e da ação dramática. A literatura confirma e nega, propõe e denuncia, apoia e combate, fornecendo a possibilidade de vivermos dialeticamente os problemas (CANDIDO, 2011, p. 177).

O texto literário apresenta traços do funcionamento histórico e social das comunidades, pois é produzido por um autor, inserido em uma determinada época e em um determinado local que, ao escrever, já está pensando sobre o seu possível leitor/receptor. Nesse contexto, é necessário 
pensar sobre o texto literário como um objeto histórico-social que, além de ser usado como elemento capaz de despertar o gosto pela leitura, é, também, uma forma de possibilitar que esse leitor/receptor seja inserido numa sociedade historicamente constituída pela palavra. Sobre essa reflexão, Magnani (1989) pontua que,

[...] falar em leitura e literatura é falar de um fenômeno social que envolve as condições de emergência e utilização de determinados escritos, em determinada época; é pensálas do ponto de vista de seu funcionamento sóciohistórico, antes e para além de platônicos e redutores juízos de valor (MAGNANI, 1989, p. 28).

No âmbito escolar, o texto literário vem sendo utilizado como aliado ao letramento, pois é visto como elemento de enriquecimento cultural, desde que utilizado adequadamente. Assim, torna-se necessário pensar em experiências que conduzam o leitor iniciante não só ao entretenimento, mas à apreensão das peculiaridades que constituem o texto literário.

Na fase inicial de leitura, devem aí prevalecer os aspectos lúdicos e de encantamento que, normalmente, os textos literários, mais indicados às crianças, incorporam em sua tessitura. Já o jovem leitor deve ter contato com obras que ampliem seus horizontes, proporcionem novos sentidos ao que lê e, ao mesmo tempo, que o seduzam e o encantem por meio dos elementos que se apresentam no texto, ou seja, as estratégias escriturais que tornam o texto literário em uma obra de arte. Nesse contexto, Jauss (1979) explicita que,

[...] a experiência estética não se inicia pela compreensão e interpretação do significado de uma obra; menos ainda, pela reconstrução da intenção de seu autor. A experiência primária de uma obra de arte realiza-se na sintonia com (Einstellung auf) seu efeito estético, isto é, na compreensão fruidora e na fruição compreensiva. Uma interpretação que ignorasse esta experiência estética primeira seria própria da presunção do filólogo que cultivasse o engano de supor que o texto fora feito, não para o leitor, mas sim, especialmente, para ser interpretado (JAUSS, 1979, p. 46). 
Jauss (1979, p. 46) orienta que o trabalho com a literatura deve ser realizado envolvendo duas tarefas da hermenêutica literária, sendo elas: tornar claro o efeito e o significado do texto para o leitor contemporâneo e, ao mesmo tempo, explicitar o processo histórico em que o texto é recebido não apenas por esse leitor, mas por leitores de outras épocas.

Esse é um trabalho que pode ser realizado desde as atividades de alfabetização e letramento, uma vez que são concebidos como processos interrelacionados, até atividades de análise mais aprofundadas que requerem já a conscientização de que, na arte literária, se efetiva, em diferentes graus e com diferentes propósitos, a manipulação da linguagem. Consideramos essa etapa - a do leitor consciente - já um estágio avançado da formação do leitor literário na escola.

Para Geraldi (1997, p. 167), “o texto é, pois, o lugar onde o encontro se dá", é o elo entre o autor, que tem o que dizer e faz uso de estratégias que explicitam as ideias que se materializam no próprio texto; e o leitor, que desempenha o papel de reconstituir o que lê por meio de suas próprias ideias. Dessa forma, é pela leitura da palavra expressa pelo autor que o leitor apreende formas diversificadas de pensar e elaborar seu próprio pensamento.

Essa dinâmica imprime significado ao texto lido pelo leitor ativo, e efetua aquilo que Jauss (1979) chama de preenchimento dos vazios do texto. Ao atribuir sentidos significativos ao texto, o leitor desempenha, também, seu papel de coautor. Esse se caracteriza pela atuação ativa do leitor com o material textual a fim de imprimir-lhe um sentido e um valor pessoal. Mediado pelo professor, esse processo pode ser realizado já nas primeiras séries do Ensino Fundamental.

Assim também ocorre ao focalizarmos o texto literário no âmbito das interações comunicativas, pois "o texto ficcional não se coloca simplesmente fora de uma situação de comunicação, [...], mas sim que a ficção se refere a uma situação comunicacional implícita." (STIERLE, 1979, p. 147).

Desse modo, devemos considerar que o texto ficcional não tem como durante muito tempo se chegou a crer - a "obrigação" de retratar a "realidade". Há momentos em que este texto está mais próximo de uma representação da factualidade e há outros em que se apresenta mais distante, 
por isso possibilita reações no leitor que o conduzem à interpretação, à reflexão ou, ainda, à crítica, alterando o seu horizonte.

A literatura infantil oportuniza os primeiros contatos do leitor com o livro de literatura, com a ficção, com o maravilhoso e o imaginário. "A obra literária é um objeto social" (LAJOLO, 1988; YUNES; PONDÉ, 1988), pois, além de promover a interação entre o autor e o leitor, é o resultado de conhecimentos que são estabelecidos em uma sociedade constituída por valores culturais, econômicos e políticos. Ela pode apresentar ideologias de diferentes sociedades. Ela faz uso especial da linguagem para concretizar esses valores que, no processo ativo de leitura, vão interagir com aqueles do universo do leitor, provocando reações que vão operacionalizar os sentidos e construir os significados.

Se a obra literária impuser ao leitor comportamentos moralizantes e regras de conduta, estará submetendo-o a uma situação de submissão, reforçando a ideia de que a escola promove uma ideologia burguesa dominante, como foi comum em certa época histórica. Grande parte da literatura infantil e juvenil mais atual é já emancipadora, desperta à criatividade e permite ao leitor a sua expressão estética.

A literatura, concebida como arte humanizadora, que tem a capacidade de suprir uma necessidade universal de ficção e fantasia (CANDIDO, 1972), pode ser instrumento para sensibilizar o leitor e auxiliá-lo na forma de ver o mundo que está ao seu redor, pois, de modo geral, esta arte nos coloca frente às questões universais de nosso tempo ou de sociedades passadas, instiga à curiosidade, ao pensamento e ao debate sobre essas questões e impulsa para as necessárias comparações.

No entanto, em sociedades que se constituíram a partir de processos de colonização - onde ler e escrever foram sempre armas de dominação controladas pelas elites do poder -, a escola ainda é o local onde a literatura se faz mais presente na vida do aluno, pois, nessas sociedades, há necessidades vitais mais urgentes no seio das famílias que o investimento em livros.

É, portanto, no espaço escolar que se ensina a manusear o livro, a lêlo da esquerda para a direita, a descobrir o sentido de palavras e a formação de frases e parágrafos e, a partir desses passos básicos, expandir o entendimento 
à arte que os constitui. Para pensar a formação desse leitor - nascido em um espaço historicamente territorializado por uma ideologia dominante que segrega, exclui, explora e escraviza - é necessário compreender que este pode interpretar o que lê - e, desse ponto, expandir sua visão aos aspectos peculiares do texto literário. Este procedimento mediador do professor, entre outros pontos, permite ao aprendiz, ao longo de sua caminhada, compreender os processos de manipulação da linguagem como material que constituiu a arte literária.

Se as crianças forem ensinadas a fazer isso, irão tornar-se, nesse processo contínuo de formação de um leitor literário, em leitores conscientes, ou seja, sujeitos de posse do conhecimento que a linguagem é um material discursivo, manipulável e ideológico. A reflexão sobre os temas que permeiam essa leitura é o mesmo que o pensar sobre o pensamento do outro, dialogar com as proposições do texto e, nessa interação, assumir o ativo papel de coautor, dando significado próprio ao que se lê como arte.

Ao visarmos à realização de um trabalho com o leitor iniciante, essa análise literária deverá apontar questionamentos que lhe permitam contrastar a realidade e a constituir conhecimentos com base nos seus próprios saberes, seja para ampliá-los ou redimensioná-los. No entanto, isso deve ser feito com a presença da fantasia, introduzida por meio de elementos fantásticos, mágicos, misteriosos, que atraem a atenção e a curiosidade desse leitor em fase inicial de formação.

Nesse engajamento do pequeno leitor com o texto literário, podemos nos valer, também, da ludicidade para conquistar esse aprendiz e fazer da prática de leitura um momento de prazer, de compartilhamento, de expressão emotiva e de ampliação de visão.

Para Yunes e Pondé (1998, p. 47), “a fantasia é uma maneira de traduzir a realidade, uma forma de conteúdo e não o conteúdo ele mesmo." Dessa maneira, o leitor ainda iniciante, ao realizar uma leitura permeada de fantasia, pode estabelecer conexões entre a leitura e as suas sensações, seus sentimentos e emoções.

Ainda sobre a fantasia, Zilberman (2003, p. 49) pontua que ela 
[...] é um importante subsídio para a compreensão do mundo por parte da criança: ela ocupa as lacunas que o indivíduo necessariamente tem durante a infância, devido ao seu desconhecimento do real; e ajuda-o a ordenar novas experiências, frequentemente fornecidas pelos próprios livros.

Assim, por meio dos livros dirigidos às crianças em fase de alfabetização e do fantástico presente neles, o leitor infantil vai construindo conhecimentos sobre a própria literatura, sobre o uso especial da linguagem contida nessa arte e sobre a experiência leitora de que não há limites entre a fantasia e a realidade na obra literária.

Essas descobertas podem auxiliá-lo a conhecer melhor a realidade à sua volta, pois, ao identificar-se com o herói, ou com o vilão, ou ainda com o local onde se passa a história ou com qualquer elemento que permeia a obra, esse indivíduo também se torna capaz de pensar sobre as pessoas e sobre as situações cotidianas, sob as quais é ancorado seu universo real, num intenso processo de comparação, aproximação, distanciamento e reordenação.

A criança leitora vale-se da "ilusão, uma etapa mais primária da recepção" (STIERLE, 1979, p. 149), em que "ela encontra, sobretudo nos contos infantis, a concretização das experiências elementares e pré-conceituais de angústia, de esperança, de felicidade e desgraça, do misterioso e do apavorante." (STIERLE, 1979, p. 149).

Além disso, os contos fantásticos, os contos de fadas e muitas histórias infantis apresentam forças opostas como o bem e o mal, virtudes que se contrapõem, como o belo e o feio, a força e a fraqueza e esses elementos permitem que a criança constitua-se e reconheça esses valores culturais que permeiam a vida em sociedade.

Stierle (1979) apresenta a seguinte reflexão sobre a recepção estética de uma obra literária:

A recepção abrange cada uma das atividades que se desencadeiam no receptor por meio do texto, desde a simples compreensão até a diversidade das reações por ela provocadas - que incluem tanto o fechamento de um livro, como o ato de decorá-lo, de escrever uma crítica ou ainda 
de pegar um papelão, transformar em viseira e montar a cavalo (STIERLE, 1979, p. 135-136).

Desse modo, a formação do leitor literário, que se inicia nos anos iniciais, na escola - ou antes disso, se esse indivíduo pertencer a uma família que possibilita o contato com os livros - é um processo e, como tal, demanda tempo, pois vai ocorrer durante todos os anos escolares, se o estudante for exposto a metodologias dinâmicas e emancipatórias, estendendo-se, daí, para toda a vida.

Sobre o processo de aquisição da leitura e sobre a formação do leitor literário, Fleck (2017, p. 26) explicita que

[...] este processo tem seu início nos primeiros anos de vida, nos contatos iniciais da criança com o mundo mágico, fantástico e aberto da literatura infantil, cujo acesso garante o aprimoramento do processo de aprendizagem da linguagem como meio de construção e representação da realidade.

Nessa perspectiva, os primeiros contatos do leitor infantil com a leitura na escola vão, aos poucos, sendo intensificados, por meio de ações sistematizadas, até que este desenvolva o gosto pela leitura e a capacidade de reflexão acerca do texto lido, mas isso requer tempo e planejamento. Portanto, o professor iniciará esse processo nas séries iniciais e os resultados dos procedimentos efetuados já nessa fase de escolarização serão observados ao longo de toda a fase adulta do sujeito, quando este pode, de fato, chegar a atuar, conscientemente, como um leitor crítico.

Dessa forma, a literatura é um dos maiores componentes culturais em uma sociedade, senão o maior, e materializa-se por meio das obras literárias que fazem uso da palavra, essencialmente escrita, mas, também, por meio de produções imagéticas e orais.

Assim, o leitor/receptor, de certa forma, entra no jogo de palavras/imagens proposto pelo autor, deixa de lado sua realidade circundante e limitada e passa a viver aventuras pelas ações das personagens de ficção, elaborando um campo plurissignificativo, que possibilita diversas leituras, as 
quais vai ajustando à sua realidade e aos seus conhecimentos, conforme vai avançando na leitura do texto.

Para Bordini e Aguiar (1988, p. 15), a literatura também pode ser considerada "uma reserva de vida paralela, onde o leitor encontra o que não pode ou não sabe experimentar na realidade." Esse aspecto da arte literária é também destacado pelo ganhador do Prêmio Nobel de Literatura, o peruano Vargas Llosa (2002, p. 394), ao expressar que,

[...] la literatura nos permite vivir en un mundo cuyas leyes transgreden las leyes inflexibles por las que transcurre nuestra vida real, emancipados de la cárcel del espacio y del tiempo, en la impunidad para el exceso y dueños de una soberanía que no conoce límites ${ }^{4}$.

Nesse transcurso, a relação signo/significante pode estabelecer-se dentro do próprio universo ficcional (como é comum ocorrer com os seres fantásticos que unicamente habitam o espaço imaginário, ficcional: fadas, duendes, gnomos, centauros, ogros, bruxas, feiticeiros, elfos, animais fantásticos, etc.) e não necessariamente no contexto real de existência do leitor.

Segundo Coelho (2017, p. 54-55), "as forças da fantasia, do sonho, da magia, da imaginação, do mistério, da intuição, etc. são desencadeadas como novas possíveis formas de representação da experiência humana" e todos esses elementos encontram força por meio da literatura infantil, possibilitando que esse leitor iniciante seja conduzido, ainda que inconscientemente, a pensar sobre sua vida. Ao refletir sobre a ação da bruxa, da fada, do príncipe, poderá refletir, também, sobre fatos reais que o conduzem a uma dificuldade, a um perigo ou a uma vitória.

Diante do exposto, propusemo-nos a estruturar uma sequência de "Oficinas literárias temáticas" que tem como base a utilização de textos literários que apresentam ao leitor iniciante "O mundo encantado das fadas", contendo letras de canção, poemas e contos, que, além das fadas, também apresentam a esse jovem leitor outros elementos desse mundo de fantasia

\footnotetext{
${ }^{4}$ Nossa tradução: [...] A literatura nos permite viver em um mundo cujas leis transgridem as leis inflexíveis através da qual passa nossa vida real, emancipados da prisão do espaço e do tempo, na impunidade do excesso e donos de uma soberania que não conhece limites.
} 
repleto de imagens que foram sendo constituídas desde o contato com as primeiras histórias infantis que eram apenas narradas a ele.

Para a realização desse trabalho, ancoramo-nos na Teoria de Literatura Comparada e Intertextualidade, de Mendoza Fillola (1994), na qual o leitor estabelece relações entre a obra lida e outras obras, por meio de conhecimentos linguísticos, metalinguísticos e culturais, adquiridos previamente, que possibilitam a construção de novos sentidos, ao estabelecer um processo de comparação, aproximação e distanciamento entre objetos e experiências de leitura já efetuadas com aqueles materiais em curso no ato da leitura atual.

Sobre esta metodologia, apresentamos a reflexão de Mendoza Fillola (1994), que expressa:

El enfoque comparatista requiere la copresencia de varios textos, es decir, producciones concretas sometidas a la observación directa del alumno. [...] destaquemos que las propuestas elaboradas a partir de los procedimientos de la LC [Literatura Comparada] pueden ser aplicables a todos los niveles de la enseñanza, desde el nivel de Educación Infantil (por ejemplo, con la utilización de producciones propias de la literatura oral o narraciones de la literatura popular o folclórica) ${ }^{5}$ (MENDOZA FILLOLA, 1994, p. 24-25).

Além disso, Mendonza Fillola (1994) expõe uma série de encaminhamentos metodológicos de trabalho com o texto literário em busca de promover o aperfeiçoamento do estabelecimento de intertextualidades. Entre os procedimentos de leitura sugeridos estão a proposição de ações que possibilitam estabelecer comparação entre as obras lidas, obras de arte, como também a integração de conhecimentos culturais que permeiam diferentes áreas de conhecimento para, assim, auxiliar o leitor a reflexões sobre a leitura e como a temática nela abordada se apresenta na sociedade em que o leitor se

\footnotetext{
${ }^{5}$ Nossa tradução: A abordagem comparativa requer a co-presença de vários textos, ou seja, produções concretas sujeitas à observação direta do aluno. [...] enfatizamos que as propostas elaboradas a partir dos procedimentos da LC [Literatura Comparada] podem ser aplicáveis a todos os níveis de ensino, desde o nível de Educação Infantil (por exemplo, com o uso de produções próprias da literatura oral ou narrativas da literatura popular ou folclórica). (MENDOZA FILLOLA, 1994, p. 24-25).
} 
insere, seja para confirmar certos conhecimentos, ampliá-los, revisá-los ou para refutá-los e reformulá-los.

Desse modo, ao final das “Oficinas literárias" o leitor terá constituído certos conhecimentos sobre uma temática específica e as diversas formas sob as quais ela se apresenta na literatura, aprofundando aspectos sobre questões culturais que se manifestam nas obras lidas e sobre a constituição da linguagem utilizada nas histórias infantis.

Ressaltamos a presença das fadas nas leituras que planejamos no decorrer das "Oficinas literárias temáticas". Isso se deve ao fato de serem elas seres encantadores, que se apresentam sob a forma humana. No entanto, são imaginadas com características que as diferenciam destes, como as asas, os poderes mágicos, tornando-as seres superiores em determinados aspectos. Elas têm o poder de realizar aquilo que os seres humanos limitam-se a sonhar. Para Coelho (2017), "limitado pela materialidade do seu corpo e do mundo em que vive, é natural que o homem tenha desejado sempre uma ajuda mágica."

Esse sentimento de satisfação da realização de sonhos e de fantasias fica mais evidente ao procedermos às leituras com esse leitor ainda criança, pois ele expõe suas ideias, sua forma de pensar e estabelece conexões com sua vida sem medo de julgamentos e sem constrangimentos. Devido à pouca idade, entrega-se, de fato, à leitura e às reflexões decorrentes dela. Vejamos, na sequência, um Módulo de nosso projeto de "Oficinas literárias temáticas", voltado ao "Mundo encantado das fadas".

\section{Oficinas literárias temáticas: Módulo I-O meu mundo encantado}

Tema da Prática: Relações possíveis entre as obras Peppa e a fada do dente $^{6}$, de Neville Astley e Mark Baker (2014), trecho do filme "O fada do dente" (2010), Vídeo “A fada do dente banguela" (2017), adaptado do livro A fada do

\footnotetext{
${ }^{6}$ ASTLEY, N. Peppa e a fada do dente. São Paulo: Salamandra, 2014.

7 Filme "O Fada do dente", produzido em 2010, pelo diretor Michael Lembeck, duração de 101min. Disponível em: https://www.youtube.com/results?search_query=filme+o+fada+do+dente+completo. Acesso em: 23 mar. 2020.

${ }^{8}$ Vídeo do Youtube, extraído do canal de contação de histórias "O Baú da Camilinha" produzido em 14 set. 2017, Disponível em: https://www.youtube.com/watch?v=5vv-L5v5dzQ. Acesso em: 06 mar. 2020.
} 
FORMAÇÂOO DO LEITOR LITERÀRIO NO ENSINO FUNDAMENTAL: UMA EXPERIÊNCIA COM "0 MUNDO ENCANTADO DAS FADAS"

dente banguela9, de Lulu Lima (2016) e a obra pictórica "Surprise Visitors ${ }^{10 "}$, de Josephine Wall (2012-2020).

Como sugestão para o Módulo I, selecionamos obras que apresentam diferentes "fadas do dente" e "o fada do dente" que, de certa maneira, representam o sentimento da esperança às crianças, pois propõem-se a realizar seus sonhos e seus pedidos em troca do dente que lhes acabou de cair. Também são histórias que possibilitam a aquisição de conhecimentos sobre leitura e literatura de maneira lúdica. O módulo está planejado para uma duração de, aproximadamente, nove horas. Para ele escolhemos o subtema "Meu mundo encantado", pois tem o propósito de trazer ao ambiente escolar não apenas as obras estudadas pelos alunos, mas as histórias vivenciadas por eles.

Apresentação das obras e determinação do horizonte de expectativas: Na primeira etapa do módulo, sugerimos que a sala seja preparada com colchonetes, com as carteiras dispostas em semicírculo, com projetor de multimídia, com ilustrações sobre o tema nas paredes e materiais que poderão ser utilizados pelos alunos como cartolinas, papéis sulfite, canetinhas, lápis de cor, tesourinha, entre outros, pois, nos momentos de ouvir histórias ou ler, poderão estar nos colchonetes e, durante as atividades de registro ou pintura, poderão ficar em suas carteiras. O subtema deverá ser exposto em painel ou cartaz. Após informados sobre o subtema e instalados adequadamente para o início das atividades, o professor pode propor um diálogo a respeito do ambiente e sobre as imagens que o decoram e, a partir das informações fornecidas pelos alunos, será possível reconhecer o que o grupo de leitores já conhece ou não sobre o tema. Dessa forma, estaremos estabelecendo o horizonte de expectativas do leitor que será, no decorrer das leituras e atividades realizadas, confirmado ou redimensionado.

Recepção e análise das obras: A primeira sugestão é mostrar aos alunos a capa do livro Peppa e a fada do dente (2014), de Neville Astley e Mark Baker e perguntar-lhes sobre como a personagem se apresenta nessa capa. O (A) professor(a) pode oportunizar um diálogo sobre o autor, o ilustrador e outros elementos de identificação, e também questionar como será essa

\footnotetext{
${ }^{9}$ LIMA. L, A fada do dente banguela. São Paulo: Martins Fontes, 2016.

${ }^{10}$ Quadro da artista Josephine Wall. Disponível em: https://josephinewall.co.uk/art-gallery/fairies/. Acesso em: 06 mar. 2020
} 
história e, a partir das informações fornecidas pelos alunos, será possível reconhecer o que o grupo de leitores já conhece ou não sobre o conteúdo observado e poderão levantar hipóteses sobre o texto, se possível registrar as hipóteses no quadro. Em seguida, sugerimos que o(a) professor(a) leia em voz alta e de forma dramatizada para os alunos. Questioná-los, após a leitura, para que verifiquem se as hipóteses levantadas e registradas na versão deles se confirmam ou não. Nesse momento, deixar que explicitem o que compreenderam sobre a história e relatem aos colegas o que ocorre com seus dentes que vão caindo e observar, de acordo com os relatos, em quais famílias os dentes das crianças são entregues à "Fada do Dente".

Depois disso, rever as ilustrações do livro para que os alunos façam a narrativa oral da obra, e assim poderão identificar aspectos naturais ou fantásticos, expressando o que lhes chama a atenção nas ilustrações. Essa narrativa será conduzida pelo(a) professor(a) e, mais tarde, servirá para compará-la com a versão do autor. É importante que os alunos vejam que a história que eles estão criando está sendo registrada no quadro ou em cartaz, para que reconheçam o quanto a escrita é útil e importante, por isso, o(a) docente deve ir "negociando" com eles os registros.

Na sequência, sugerimos que os alunos sejam convidados a assistir um trecho do filme "O fada do dente" (2010), perguntar-lhes se já assistiram ao filme e se teriam alguma informação para compartilhar com os colegas. Antes de iniciar a seção de cinema, propomos uma brincadeira saborosa: distribuir pipoca doce a todos e alertar os alunos que o(a) professor(a) jogará um pozinho mágico (utilizamos o açúcar colorido) sobre os pacotinhos de pipoca. Em nossa brincadeira, acrescentamos que, após comê-las, cada aluno conseguirá praticar ações que demonstram bondade, amizade e que o dia será melhor, assim como acontecerá na vida da personagem do filme que vamos assistir. Essa atividade estará envolvendo os sentidos da visão, da audição e do paladar, para que os conhecimentos constituídos sobre a linguagem sejam acionados por meio dos sentidos.

Ao término do filme, pedir que relatem algumas cenas e o que sentiram ao assisti-las, aproveitar o momento para perguntar o que mudou na vida da personagem após tornar-se um fada do dente. Espera-se que os alunos notem que, antes da transformação, a personagem era egoísta, preocupava-se 
com sua aparência, com a fama e com o dinheiro e agia de forma desumana com seus semelhantes.

Nesse momento devem ser registradas, em papel sulfite ou cartolina, as palavras que representam os sentimentos que podem ser identificados nos relatos dos alunos. Cada aluno pode fazer o seu registro e o(a) professor(a) poderá auxiliar o aluno que está se apropriando da escrita, depois pedir que disponham as palavras no painel em que foi apresentado o subtema do módulo.

No próximo encaminhamento, sugerimos a história narrada no vídeo "A Fada do Dente Banguela", que apresenta uma "fada do dente" que ficou banguela. Este vídeo é produzido e disponibilizado pelo canal "O Baú da Camilinha", do Youtube, sendo a própria Camilinha a contadora da história. Nesse momento, questionar sobre o sentido da palavra "banguela" e sobre o fato de a "fada do dente" também encontrar-se na mesma situação em que ficam as crianças as quais deve socorrer. Ouvir os comentários dos alunos, organizando-os de modo que todos os interessados possam expor suas ideias, explicar-lhes que a história que acabaram de ouvir é a mesma do livro $A$ fada do dente banguela (2016), de Lulu Lima, mostrar o livro aos alunos e recontá-la, pausadamente, para que possam observar as ilustrações e comentar sobre o tema livremente.

Em seguida, distribuir aos alunos a caderneta "Dentinho mágico" (uma espécie de caderneta produzida pelo(a) professor(a), em cuja capa há um dentinho sorridente, personificando esse elemento que esteve presente nas obras trabalhadas). Na caderneta, os alunos podem representar a história ouvida por meio de ilustrações. Se algum aluno quiser fazer o registro escrito também poderá fazê-lo; a personagem da abertura da caderneta poderá ser ilustrada com cola glitter ou conforme a preferência do aluno.

Em seguida, sugerimos a análise da pintura "Surprise Visitors" (20122020), da artista Josephine Wall, utilizando o projetor de multimídia, oportunizando o momento para que os alunos relatem como essa tela se relaciona com as outras histórias que integram este primeiro módulo, pois apresenta a representação pictórica de uma criança recebendo a visita de muitas fadinhas, à noite, em seu quarto. Para esse encaminhamento, sugerimos que o(a) professor(a) distribua a imagem colorida da obra de Josephine Wall (2012-2020) aos alunos, propriamente identificada, no tamanho 
do sulfite, recortada em forma de quebra-cabeça, possibilitando que a remontem e a colem em outro papel com espessura mais firme que a do sulfite;

Ao final do Módulo, acrescentar ao painel - que já contém o subtema "Meu mundo encantado" e as palavras que representam emoções - uma imagem sobre cada personagem analisado por meio das obras selecionadas para essa etapa, denominando-as para que os alunos possam se lembrar das obras analisadas. As atividades produzidas pelos alunos poderão ser guardadas ou encaminhadas aos responsáveis de acordo com os procedimentos habituais de cada docente.

Integração de conhecimentos culturais. Nesse momento sugerimos que o(a) professor(a) peça aos alunos que pesquisem junto aos pais, avôs e avós, o que faziam com os dentes que caíam quando eram crianças. Desse modo, no próximo encontro, deverão narrar aos colegas as histórias contadas pelos familiares. Com isso, estaremos estabelecendo a integração de conhecimentos culturais de diferentes gerações.

Conclusões. Para verificarmos se os alunos estão constituindo conhecimentos a respeito das leituras e análises das obras, sugerimos que o docente analise as ilustrações da caderneta, os relatos orais, os argumentos apresentados pelos alunos e/ou registros escritos, considerando o ano escolar em que se encontram.

Propomo-nos, ao longo dos encontros literários, possibilitar momentos de reflexão, de modo que as leituras e análises oportunizem o acesso a conhecimentos que vão além do que está escrito ou visualizado, pois há momentos de pesquisa e de compartilhamento de conhecimentos. Além disso, queremos promover momentos de ludicidade por meio da realização de brincadeiras, de atividades orais, de registros realizados com ilustrações.

\section{Considerações Finais}

A literatura infantil possibilita que o leitor iniciante seja sensibilizado ao conhecer a obra e sua constituição, pois ela é instrumento de aquisição de conhecimentos e de valores culturais, além de ser primordial para desenvolver a reflexão sobre conceitos, sobre temas e sobre a linguagem presente nas obras literárias. 
Para Candido (2011, p. 179), “a organização da palavra comunica-se ao nosso espírito e o leva, primeiro, a se organizar; em seguida, a organizar o mundo". Dessa forma, o autor explicita uma análise sobre como a literatura contribui para a constituição do indivíduo, como ele se situa enquanto ser social e como passa a pensar sobre si e sobre seu lugar no mundo.

Dessa forma, ao estruturarmos "Oficinas literárias temáticas", estaremos oportunizando ao jovem leitor (re)conhecimentos sobre alguns elementos fantásticos que permeiam as histórias de fadas e que isso contribua para que possa, também, continuar lendo e se "encantando" com o mundo da literatura e que, por fim, ele constitua seu próprio "mundo encantado da leitura".

Ler uma série de textos multimodais, amalgamados sob uma temática comum, oportuniza ao leitor, mesmo àquele de menos idade, a aprofundar sua experiência de leitura e, assim, constituir um sentido e um posicionamento pessoal, para o universo abordado, sem estar desviando-se por encruzilhas multitemáticas, abordadas de forma rasa, num tempo muito curto e sem mostrar a gama de inter-relações possíveis de se alcançar no processo de leitura.

\section{Referências}

CANDIDO, Antonio. (1972). A literatura e a formação do homem. Ciência $e$ Cultura. São Paulo, v. 24, n. 9, p. 803-809.

CANDIDO, Antonio. (2011). O direito à literatura. In: Vários escritos. 5. ed. Rio de Janeiro: Ouro Sobre Azul.

COELHO, Nelly Novaes. (2017). Literatura infantil: Teoria, análise e didática. São Paulo: Moderna.

FLECK, Gilmei Francisco. Formação do leitor: um projeto socioeducacional uma trajetória para a vida cidadã. In: FLECK, Gilmei Francisco (Org.), 2017. Literatura Infantojuvenil: desafios para o letramento literário - pesquisas e experiências no âmbito escolar. Curitiba: CRV, p. 23-37.

GERALDI, João Wanderley. (1997). Portos de passagem. 4.ed. São Paulo: Martins Fontes. 
JAUSS, Hans Robert. Estética da recepção: colocações gerais. In: LIMA, Luiz Costa (trad. e org.), 1979. A literatura e o leitor - textos de estética da recepção. Rio de Janeiro: Paz e Terra, p. 43-61.

JAUSS, Hans Robert. O prazer estético e as experiências fundamentais da poiesis, aisthesis e katharsis. In: LIMA, Luiz Costa (trad. e org.), 1979. A literatura e o leitor - textos de estética da recepção. Rio de Janeiro: Paz e Terra, p. 63-82.

LAJOLO, Marisa. (1982). O que é literatura. 9.ed. São Paulo: Brasiliense

MAGNANI, Maria do Rosário Mortatti. (1989). Leitura, literatura e escola: a formação do gosto. São Paulo: Martins Fontes.

MARTINS, Maria Helena. (1983). O que é leitura. 2.ed. São Paulo: Brasiliense. (Coleção Primeiros Passos).

MENDOZA FILLOLA, Antonio. (1994). Literatura comparada e intertextualidad. Madrid: Editorial La Muralla, S.A.

STIERLE, Karlheinz. Que significa a recepção dos textos ficcionais? In: LIMA, Luiz Costa (trad. e org.), 1979. A literatura e o leitor - textos de estética da recepção. Rio de Janeiro: Paz e Terra, p. 133-188.

VARGAS LLOSA, Mario. (2000). La verdad de las mentiras. Barcelona: Seix Barral, 1996; Buenos Aires: Alfaguara.

ZILBERMAN, Regina. (2003). A literatura infantil na escola. 11.ed. São Paulo: Global, 2003.

Recebido em 29 de abril de 2020.

Aceito em 20 de junho de 2020. 